\title{
Tree diversity patterns along the latitudinal gradient in the northwestern Russia
}

\author{
Elena Tikhonova ${ }^{1 *}$, Gleb Tikhonov², Nikolay Shevchenko', Svetlana Knyazeva', Alexandra Plotnikova', \\ Natalia Lukina ${ }^{1}$ and Maxim Shashkov ${ }^{3}$
}

\begin{abstract}
Background: One of the key forest characteristics is the biodiversity, particularly the diversity of trees which are forest ecosystem engineers. Nowadays the most worldwide common approach for assessment of forest conditions and dynamics is based on the systematic monitoring, performed at a set of regularly structured plots. To fulfill the existing gap in this sort of knowledge on the Russian forests, an extensive study of tree species diversity on a regular network was conducted in north-west of Russia.

Methods: The study used the ICP Forests monitoring network that spans over $1700 \mathrm{~km}$ along the western Russian border from forest-tundra in the north to broadleaved-coniferous forests in the south. Tree data were collected at 710 sites that were assigned along a regular grid. We performed series of statistical analyses of the tree species distribution and diversity in relation to environmental and anthropogenic factors.

Results: According to the Maxent species distribution modelling results only Pinus sylvestris, Betula sp. and Picea abies have the potential to grow throughout the study area. The locally maximum tree species diversity varies along the latitudinal gradient from 1 to 3 species in the north to 5-7 species in the south. Monocultural stands are relatively abundant across the study area, being especially common in the south taiga. The prevailing part of the monocultural stands is represented by Scots pine (72\%). The age distribution of dominant trees has a clear connection with the intensity of forest use. We found that recent wildfire events had only little effect on tree diversity in the study area.

Conclusions: We demonstrated that ICP Forests monitoring network enables to successfully establish the main qualitative and quantitative relations of the spatial variation of tree species diversity to climatic, landscape, soil and anthropogenic factors. Analysis of the influence of these factors on tree species distribution allowed us to conclude that with the continuing trend of reducing the frequency and intensity of fires, Norway spruce will further replace Scots pine and Betula sp. in the north-western Russia. Extending the monitoring network, especially adding the time-series context, could provide novel appealing opportunities for forest dynamics projection and sustainable management.
\end{abstract}

Keywords: Forest monitoring, ICP Forests, Tree diversity, Species distribution modelling, NW Russia

\section{Background}

More than $20 \%$ of forests on the Earth are located in the Russian Federation with the total area of forests exceeding 800 million hectares (FAO 2015). Among them boreal forests are prevailing with proportion $86 \%$. A credible estimate of the current forest condition and ongoing dynamics is a basis for reliable forecasts of the global changes and

\footnotetext{
* Correspondence: tikhonova.cepl@gmail.com

${ }^{1}$ Center of Forest Ecology and Productivity RAS, 117997, Profsoyusnaya 84/

32, Moscow, Russia

Full list of author information is available at the end of the article
}

sustainable forest management. Nowadays the most worldwide common approach for assessment of forest conditions and dynamics is based on the systematic ground-based forest monitoring, performed at a set of regularly structured locations (Ferretti 2013; Crowther et al. 2015). In Europe, one of the most ambitious projects on forest description on a regular basis is the International Co-operative Programme on Assessment and Monitoring of Air Pollution Effects on Forests (ICP Forests).

One of the key forest characteristics is the biodiversity, particularly the diversity of woody plants which are forest 
ecosystem engineers (Jones et al. 1994; Jones et al. 1997). There is evidence of a positive relationship between the tree species diversity and ecosystem functioning (Gamfeldt et al. 2013). Recent studies have shown that ICP Forests data can be successfully used to assess tree diversity (Tröltzsch et al. 2009; Brus et al. 2012). In Russia the monitoring network ICP Forests spans over $1700 \mathrm{~km}$ along the western Russian border and covers six northwestern regions (Lukina et al. 2013). Just as everywhere else on our planet, Russian forests are generally shaped by a combination of various factors, which can be divided into four principal groups: historic, current abiotic, biotic and anthropogenic (Huston 1994). It is recognized that the modern differentiation of the tree species composition on a latitudinal gradient is determined primarily by climate (Sykes et al. 1996; Körner et al. 2016; Vetluzhskikh 2016), and for boreal and northern temperate European forests the most important factor is temperature (Morozova 2009). However, other factors acting on different spatial scales may have a significant impact on the local patterns of tree species richness (Caley and Schluter 1997; Svenning and Skov 2005; Svenning et al. 2010). While regional factors (climate and historical) determine the regional pool of species, at a local level other factors such as soil, biotic interactions, natural disturbances and anthropogenic influence may be important. As Caley and Schluter (1997) noted it is also possible "that in natural communities a variety of such processes could interact, resulting in a complex array of outcomes". As several key fundamental studies in Russia indicated the crucial contribution of wildfires into structure and composition of forest communities (Molchanov 1934; Korchagin 1954), we specifically test the validity of this concept nowadays and pay increased attention to pyrogenic factor.

This study is aimed at assessment of tree species diversity patterns depending on combination of various natural and anthropogenic factors in Northwestern Russia.

The study addresses the following problems:

1) Assess the actual and potential distribution of tree species in Northwestern Russia and determine the key factors that are shaping the observed patterns.

2) Disentangle the impacts of climate and other environmental and anthropogenic factors that operate at different spatial scales on forest communities.

3) Evaluate relationships between stand age and intensity of forest use.

To answer these scientific questions we performed series of statistical analyses of the tree species distribution and diversity along the latitudinal gradient in Northwestern Russia based on the tree data collected within the ICP Forests monitoring programme. It is the first study on tree species diversity in the large area in European Russia, based on data from the regular grid.

\section{Methods \\ Study area}

The study region is located in the northwestern part of Russia $\left(54^{\circ} 20^{\prime} \mathrm{N}, 19^{\circ} 50^{\prime} \mathrm{E} ; 6^{\circ} 05^{\prime} \mathrm{N}, 37^{\circ} 45^{\prime} \mathrm{E}\right)$ and consists of 6 federal states: Leningrad, Pskov, Novgorod, Kaliningrad, Murmansk regions and Republic of Karelia. The terrain of this area was primarily shaped during the last glacial period. There is a clear latitudinal landscape zonation along the meridian gradient, from subarctic forest-tundra in the north to hemiboreal in the south (Fig. 1). The most highland areas are located in Murmansk region (the Khibiny Mountains) and northern part of Karelia and mainly feature dark-coniferous open forests. The lowest areas are represented by river valleys landscape and are generally situated in Kaliningrad region (The Ecological Atlas 2002). Apart of those the study area is generally dominated by boreal forest landscapes. Boreal north taiga and middle taiga forests typically occupy ridge-hilly moraines and sandy-lake plains, where crystalline hard rock surface formations are abundant. The border between north and middle taiga approximately follows the $63^{\circ} \mathrm{N}$ latitude. The north taiga is dominated by pine forests stands and the middle taiga by mixed stands of pine and spruce. Further to the south lies southern taiga landscape, which mainly span over the lowlands, moraine and lake-glacial flatlands. Many of the areas in that landscape are vast swampy sandurs. The forests in these areas are generally of secondary types (birch, aspen, grey alder). An exception is the Karelian Isthmus area, which is featured by rugged terrain, abundant hard rock outcrops and multiple lakes. Hemiboreal landscapes start approximately at the $58^{\circ} \mathrm{N}$ latitude and generally occupy the whole southern part of the study region. Mixed coniferous-broadleaf forests could be typically found in lake-glacial flatlands and lowlands that are crossed by periodic areas of ridge-hilly terrain. The prevailing forest species are spruce, pine, oak, maple, and birch. Black alder occupies the most moist lowlands.

The climate of the area varies from subarctic climate, with long and cold winters and short, cool summers, in the northernmost part to typical European continental influenced climate with warm, dry summers and fairly severe winters in the southernmost part. Similarly, the precipitation is latitudinally structured, with higher values in the south regions. The most precipitation typically fall during spring and autumn seasons. Table 1 features the key climatic characteristics for each of the bioclimatic division.

\section{Field data collection}

The study area has been a subject to the ICP Forest Programme, in scope of which a network of grid structured 


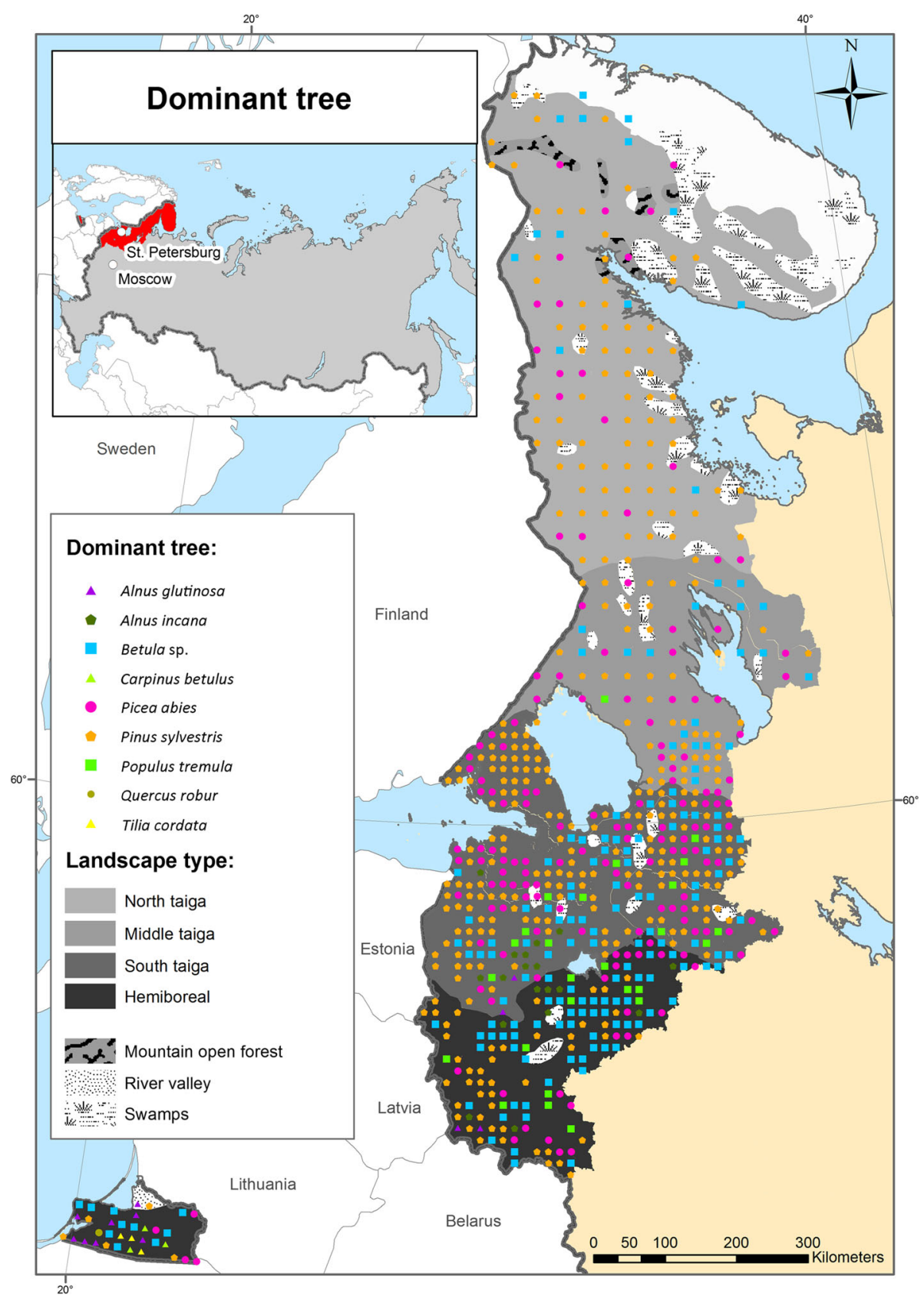

Fig. 1 Spatial distribution of landscape types and dominant tree species over the study region. The map depicts the spatial distribution of landscape types over the study region through colorscheme. Boundaries of the landscape zones are provided by the Ecological Atlas of Russia (2002). The locations of sites, where the field observations were conducted are marked with symbols, which type reflect the dominant tree species for that site

sites was monitored. It features 710 sites in total with 16,351 individual trees inventoried Additional file 1: Table S1. The grid is rectangular and spaced by $16 \mathrm{~km}$ in Leningrad and Kaliningrad regions and by $32 \mathrm{~km}$ in other regions (Fig. 1). The exact locations of sites were determined using the mobile Global Positioning System (GPS) device according to theoretically calculated coordinates. A deviation of exact site position up to $500 \mathrm{~m}$ from the theoretical coordinates was allowed in order to minimize potential issues for forest monitoring exactly in the theoretical location. The theoretical site was deprecated and observations not made in case of a) no forest stand with area of at least 0.5 ha was found in the range of acceptable deviation from the theoretical coordinates, or b) the age of dominant forest stand was less than 20 years.

At each site 4 sampling plots were established, each located at 25-m step away from the site center along one of the four cardinal directions. Each of the plots was 
Table 1 Key climatic characteristics for each of the major bioclimatic divisions represented in the study area

\begin{tabular}{lllllll}
\hline Landscape & $\begin{array}{l}\text { Average annual } \\
\text { temperature }\end{array}$ & $\begin{array}{l}\text { Max warm month } \\
\text { temperature }\end{array}$ & $\begin{array}{l}\text { Min cold month } \\
\text { temperature }\end{array}$ & Annual precipitation & Summer precipitation & Winter precipitation \\
\hline Forest-tundra & 0.1 & 14.6 & -13.6 & 344 & 126 & 38 \\
North taiga & 0.2 & 16.2 & -15.3 & 523 & 161 & 67 \\
Middle taiga & 3.6 & 20.1 & -11.4 & 751 & 197 & 108 \\
South taiga & 3.7 & 20.3 & -10.5 & 752 & 211 & 107 \\
Hemiboreal & 6.4 & 21.6 & -7.0 & 788 & 222 & 116 \\
\hline
\end{tabular}

The provided values are based on the results of temporal averaging and spatial interpolation within the landscape subdivisions of long term (1930-2010) observations from 25 meteorological stations located in the study area

circularly shaped with the radius determined by particular local forest stand: it was selected in such a manner that each plot contained 6 trees of the dominant species. Only those trees that belong to 1-3 Kraft classes were counted (Eitingen 1959; Assmann 1970). Thus, the total number of dominant trees in all 4 plots at each site was always equal to 24. Apart of those dominant species trees, all trees of other species (also belonging to 1-3 Kraft class) within the determined plots were recorded. In the case when the dominant species trees were particularly remotely located and the established sampling plots overlapped, the 25-m step from the center of site was replaced by $50-\mathrm{m}$ (or $75-\mathrm{m}$ ) step and the same plot establishing procedure was repeated. For each counted tree we recorded diameter, height, age and crown characteristics. Along with these we recorded plot fundamental properties: site's ecotope, slope exposition and local relief characteristics.

In this study we use the subset of the whole database consisting of those 547 sites, which were monitored in 2009 (Murmansk region) or 2008 (other regions).

\section{Wildfire activity}

The raw data on wildfire activity was obtained through Vega satellite imaging service using spectra-radiometric observations in 2006-2016 by MODIS sensor, mounted on TERRA and AQUA satellites (Lupian et al. 2014). The data features the coordinates of initial ignition, encounter date and spread area. For each of ICP Forests sites we selected the recorded fires that took place within the $3-\mathrm{km}$ radius circle centered at the site. We calculated the amount of fire events and burnt area within the $3-\mathrm{km}$ circle. We similarly calculated the proportions of square area that was disturbed by fire in 2006-2016 for each landscape.

\section{Statistical analysis}

We exploited various descriptive analyses to visualize and assess the patterns of community diversity and composition in relation to environmental factors, land type, fire stress and the age of dominant tree. To accommodate for potential nonlinearities in the relationships between different variables we always used Spearman rank coefficient as a measure of correlation. All descriptive analysis was run using the core $\mathrm{R}$ software ( $\mathrm{R}$ Core Development Team 2016).

We analyzed the distributions of individual species using the maximum entropy method (Phillips et al. 2006; Phillips and Dudík 2008) using MaxEnt software (version 3.3.3 k). Through this approach we related the observed patterns of species presences and absences to the various environmental covariates, that previously were found relevant for species distribution modelling in other studies (Hunter 2012). Namely we used WorldClim 30-s database (World Clim, www.worldclim.org) to obtain high resolution estimates (Hijmans et al. 2005) for the key bioclimatic variables (BIO1-BIO19, WorldClim notation, see list of abbreviations) and additionally included altitude. We used the fitted models to produce the species optimal distribution maps for the species that were abundant in the study area.

We further analyzed the species-to-species associations, explicitly accounting for the spatial structure of observed plots over the study region, with the HMSC - Hierarchical Model of Species Communities (Warton et al. 2015; Ovaskainen et al. 2016; Ovaskainen et al. 2017). This approach differs from the single species distribution modelling in that it attempts to seek strong patterns that are shaping groups of species in the observed communities simultaneously, thus sharing information between species, which is supposed to be especially beneficial in sense of statistical power for making inference on rare species' that do not exhibit sufficient signal on their own. We included only intercept to the fixed effects part of HMSC and a single spatial level of random effects, corresponding to the locations of the observed data, with the number of latent factors assumed to be estimated by the model from the data itself. With this modelling design we evaluated the spatially structured random factors that are shaping the observed communities with the amount of variation that they explained, measured as Tjur $R^{2}$, and the species-to-species cooccurrence matrix that provides 
information on which species are present together more or less often than expected under the independence hypothesis (Pollock et al. 2014).

\section{Results}

Table 2 gives the correlation analysis results for the proportions of number of certain species' trees observed at a site to the total number of recorded trees in this site and the key characteristics of the site: biodiversity, dominant forest stand age, soil fertility, moisture, and pyrogenic activity. The highest negative correlation was observed between the proportion of pine and soil fertility. Oppositely the birch was found to be positively correlated with soil fertility. The strength of species-moisture correlation was generally lower with the greatest negative correlation exhibited by spruce. Biodiversity was found to be positively correlated to soil fertility and generally negatively correlated to moisture. Pine is usually associated with narrow diversity, while proportions of spruce and birch oppositely exhibit positive correlation. The proportions of pine and spruce, as well as pine and birch showed strong negative correlation, although this could be partially attributed to specifics of sampling design. Our analysis showed that the correlations of species proportions to pyrogenic activity was generally rather low, the pine negatively correlated with measures of pyrogenic disturbance and broadleaf positively correlated.

According to the Maxent species distribution modelling results only 3 of the observed species (Picea abies, Pinus sylvestris, Betula sp.) are not theoretically restricted in their distribution due to climatic conditions over the study area (Fig. 2). The most influential factors for Pinus sylvestris distribution revealed to be the temperature characteristics: mean Diurnal range (BIO2), temperature seasonality (BIO4) and max temperature of warmest month (BIO5). Betula sp. and Picea abies also were found to be strongly dependent on these factors, but also considerably influenced by the precipitations seasonality (BIO15). The optimal distribution ranges for Alnus incana and Alnus glutinosa completely overlap with the northern border at $61^{\circ} \mathrm{N}$, and these species revealed to be most sensitive to the altitude and the precipitation of driest quarter (BIO17). Distribution of Populus tremula is concentrated in the southern regions of the study area. Our modelling results depict that it is most influenced due to $\mathrm{BIO} 4, \mathrm{BIO} 5$ and BIO17. It is also worth to mention that according to Maxent results potential distribution range of Populus tremula spans so far north as the Kola Peninsula, which considerably deviates from its observed distribution range.

The maximum tree diversity of studied forest communities had a distinguished latitudinal structure varying from typical 1-3 species encountered in the north taiga sites to 5 (occasionally 7) species encountered in south taiga and hemiboreal sites (Fig. 3a). However, the monospecies communities were rather abundant in all bioclimatic zones, with the highest proportion of mono-species communities observed in south taiga. Among the monospecies communities $72 \%$ were pine forests and $12 \%$ birch forests. Especially prevailing part of mono-species pine forests was detected in sandur parts of south taiga and lakeglacial sandy landscapes in hemiboreal zone. Rich species communities mainly consisted of spruce and broadleaf species, although spruce was not particularly associated with rich communities. These patterns revealed by descriptive analysis were further supported by the results of joint species distribution modelling, which indicated positive associations within several groups of broadleaf species and negative associations of most species with pine (Fig. 4). The HMSC estimated that there are three statistically significant latent factors, two of which were found to be spatially structured with non-zero spatial ranges (40$70 \mathrm{~km}$ ). The averaged over species Tjur $R^{2}$ was 0.34 , although it significantly varied for individual species

Table 2 Spearman rank correlations between proportions of tree species in the plot, biodiversity, stand age, two habitat properties: soil fertility and moisture, and pyrogenic activity recorded as number of fires and burnt area

\begin{tabular}{|c|c|c|c|c|c|c|c|c|}
\hline & Pinus & Picea & Betula & Broadleaf & Biodiversity & Age & Fertility & Moisture \\
\hline Pinus & 1 & -0.41 & -0.61 & -0.20 & -0.43 & 0.23 & -0.82 & 0.02 \\
\hline Picea & -0.41 & 1 & 0.09 & -0.02 & 0.58 & 0.22 & 0.24 & -0.16 \\
\hline Betula & -0.61 & 0.09 & 1 & 0.03 & 0.45 & -0.26 & 0.46 & -0.01 \\
\hline Broadleaf & -0.20 & -0.02 & 0.03 & 1 & 0.2 & 0.01 & 0.22 & -0.03 \\
\hline Biodiversity & -0.43 & 0.58 & 0.45 & 0.2 & 1 & -0.02 & 0.31 & -0.12 \\
\hline Age & 0.23 & 0.22 & -0.26 & 0.01 & -0.02 & 1 & -0.26 & 0.01 \\
\hline Fertility & -0.82 & 0.24 & 0.46 & 0.22 & 0.31 & -0.26 & 1 & 0 \\
\hline Moisture & 0.02 & -0.16 & -0.01 & -0.03 & -0.12 & 0.01 & 0 & 1 \\
\hline Number of fires & -0.18 & -0.11 & -0.03 & 0.25 & 0.03 & -0.11 & 0.28 & 0.01 \\
\hline Burnt area & -0.16 & -0.09 & -0.03 & 0.2 & 0.03 & -0.09 & 0.24 & 0.01 \\
\hline
\end{tabular}

Correlations significant with $p$-value $<0.05$ are highlighted with bold 


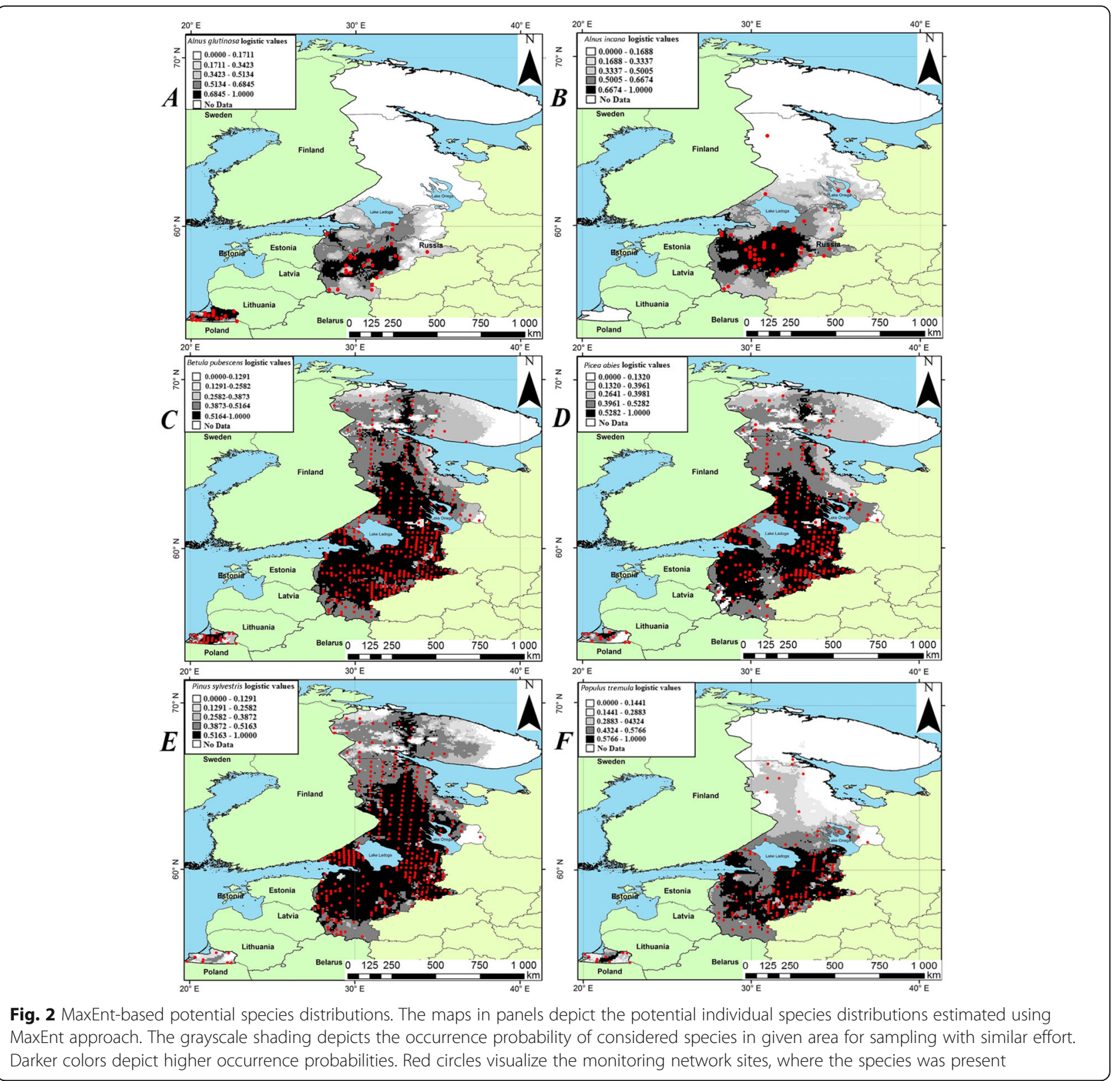

(Table 3). The third latent factor was primarily associated with increased occurrence probability of Pinus sylvestris and decreased probability to encounter any other species in the same plot. The remaining two latent factors could not be easily attributed to single species, the first latent factor seems to be associated with divisions of tree species into nemoral and boreal groups.

The spatial distribution dominant tree ages was highly uneven (Fig. 3b). The northern areas were generally represented by highly mature forests ( $>160$ years) with the most aged trees (300-330 years) being pines or spruces observed in the north taiga. Further to the south the proportion of the forest stands of age $80-120$ years increases. However, while in the Karelian Isthmus this age group is vastly prevailing, Karelian middle taiga features more heterogeneous age distribution mainly represented by middle age stands (40-80 years) with occasional more mature stands (120-160 years). More southern regions of Pskov, Novgorod and Kaliningrad generally covered by middle age forests while the mature stands ( $>120$ years) are rare.

\section{Discussion}

First of all it is worth noting that ICP Forests data have some limitations when used for analysis of tree species diversity (Tröltzsch et al. 2009). The plot density $16 \mathrm{~km} \times$ 

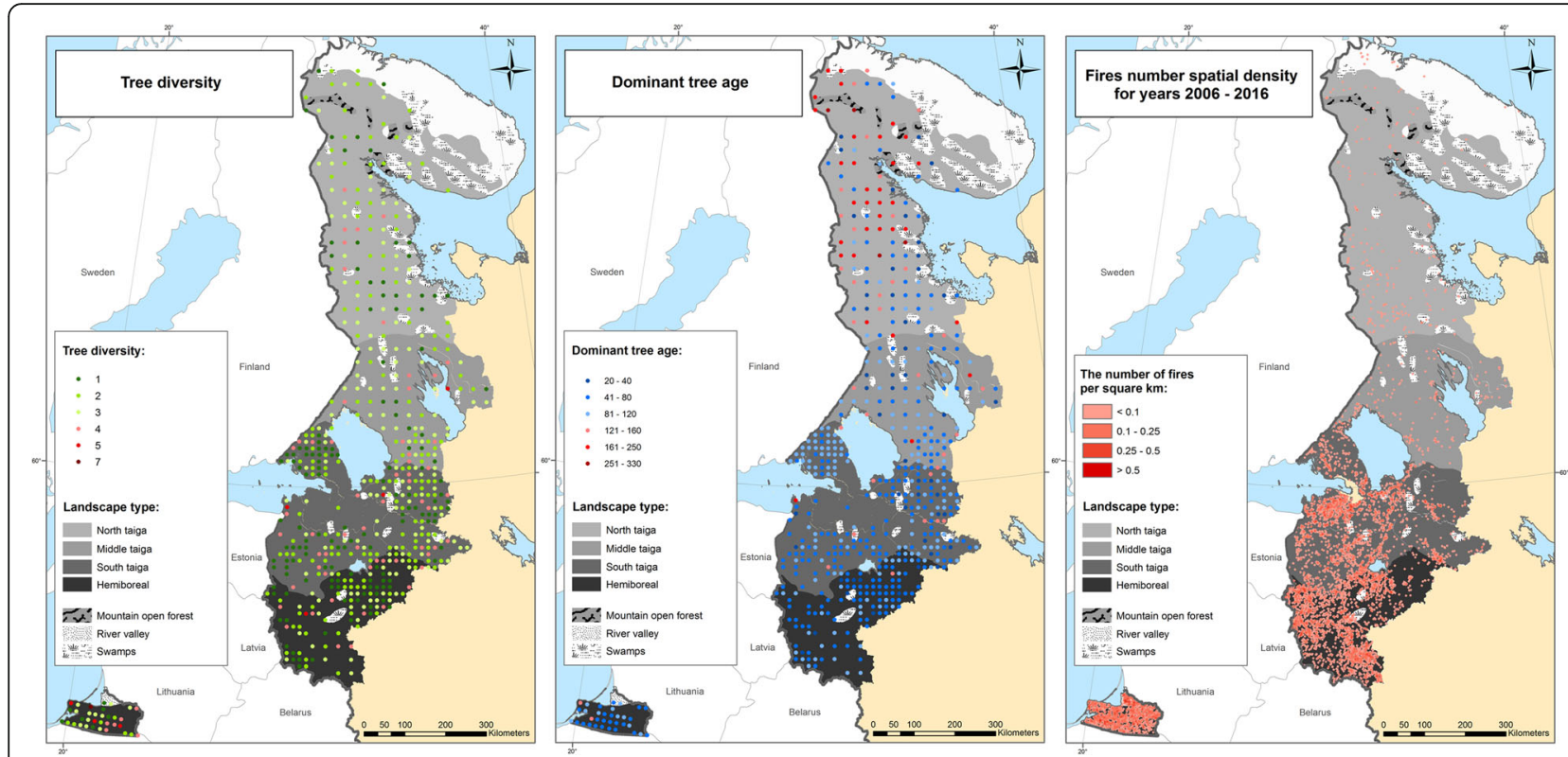

Fig. 3 Spatial distributions of tree biodiversity, tree stand age and wildfires. Panel a visualizes the tree species biodiversity at sampled monitoring network sites. Panel $\mathbf{b}$ depicts the maximum age of dominant species in the stand at sampled sites. Panel $\mathbf{c}$ demonstrates the wildfire ignition locations for the years 2006-2016

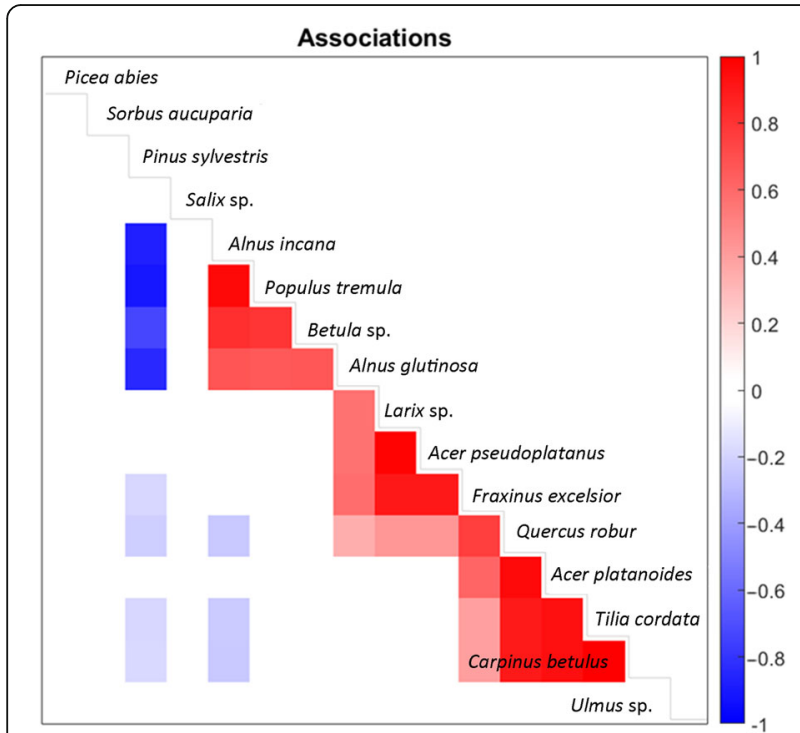

Fig. 4 Species-to-species association matrix, estimated by Hierarchical Model of Species Communities. Each matrix cell corresponds to a pair of different species and gradation of blue-red colors depict the species-tospecies estimated association strength measured at correlation scale. Red colors stand for the species that cooccur more often than expected based on the individual species' occurrence probabilities. Contrary, blue colors depict the species that tend not to cooccur. White cells indicate those pairs, where the null hypothesis of no association between given pair of species could not be rejected at the statistical significance level 0.05
$16 \mathrm{~km}$ to $32 \mathrm{~km} \times 32 \mathrm{~km}$ provides only for coarse estimation of current species distribution at the regional level. Furthermore the ICP Forests plot network includes not all trees with stems exceeding a certain diameter but those related to 1-3 Kraft's classes. Also plot areas may be not sufficient for adequately measure tree species diversity (Latham and Ricklefs 1993). However in general ICP

Table 3 Latent loadings for the HMSC and model's explanatory power measured as Tjur $R^{2}$

\begin{tabular}{lllll}
\hline Species & LatLoad1 & LatLoad2 & LatLoad3 & Tjur $R^{2}$ \\
\hline Acer platanoides & -0.018 & 0.003 & 0 & 0.13 \\
Acer pseudoplatanus & -0.011 & -0.026 & 0 & 0.61 \\
Alnus glutinosa & -0.034 & -0.053 & 0.085 & 0.26 \\
Alnus incana & 0.027 & -0.001 & 0.099 & 0.2 \\
Betula sp. & 0.02 & -0.016 & 0.073 & 0.07 \\
Carpinus betulus & -0.067 & 0.03 & 0 & 0.65 \\
Fraxinus excelsior & -0.045 & -0.041 & 0.002 & 0.55 \\
Larix sp. & -0.011 & -0.026 & 0 & 0.61 \\
Picea abies & 0.022 & -0.011 & 0.003 & 0.01 \\
Pinus sylvestris & 0.067 & 0.003 & -0.326 & 0.68 \\
Populus tremula & 0.031 & 0.017 & 0.167 & 0.22 \\
Quercus robur & -0.109 & -0.004 & 0.001 & 0.71 \\
Salix sp. & 0.003 & 0.001 & 0.002 & 0.01 \\
Sorbus aucuparia & 0.002 & 0 & 0.003 & 0.01 \\
Tilia cordata & -0.075 & 0.034 & 0 & 0.69 \\
Ulmus sp. & -0.002 & -0.001 & 0.001 & 0.01 \\
\hline
\end{tabular}


Forests plot data are considered to be representative at the regional level and there is positive experience of their use for biodiversity assessment (Tröltzsch et al. 2009; Meier et al. 2012). Finally, as it was already mentioned, for a large area in Northwest Russia these data are the only available for analysis with regular survey grid.

Extremely low tree diversity is characteristic of all Eurasian boreal forest (Wirth 2005). But woody flora of temperate European forests is significantly less diverse than flora of forests in the North America and especially in East Asia at the similar latitude range. That is usually explained by massive extinction in the Pleistocene ice ages (Huntley 1993; Latham and Ricklefs 1993; Svenning et al. 2008).

Our data clearly demonstrated the latitudinal gradient of tree species diversity - with 6 species encountered in the northern and middle taiga, 8 species in the southern taiga, and 15 in hemiboreal subzone. The highest diversity is observed in the Kaliningrad region - the most south and that is also important, the most western region in this study. It is the only region where temperate Central European tree species have been presented, e.g. Carpinus betulus and Acer pseudoplatanus. The northern limits of species distribution are generally associated with duration of growing season, while the eastern limits - with temperatures of the coldest month (Woodward and Williams 1987; Sykes et al. 1996).

Climate regulates tree species composition at the regional level; however, at the local level site-specific factors (e.g. forest fires, wind throw, topography, soil characteristics, interspecific competition and successional stage) mostly overrule the importance of regional climate (Pearson and Dawson 2003; Körner et al. 2016; Kuosmanen et al. 2016).

For example widespread distribution of monocultural pine forests in the study area could be associated with poor soils, anthropogenic influence and early stage of successions. As it was demonstrated for the area of Les Landes, SW France (Sykes et al. 1996), most of the moisture-demanding tree species were absent from the sandy soils. Slash-and-burn cultivation practices with shorter fire return intervals and agricultural deforestation also caused change towards monocultural forest structure (Kuosmanen et al. 2016).

Our results of modelling the potential distribution of tree species could be explained by ecological characteristics of these species. For example, the distribution of mesofilic species (Betula sp. and Picea abies) was limited to the areas with moist soil during the growing season in contrast to xerofilous species Pinus sylvestris, which can successfully tolerate long-term moisture deficit. The altitudinal dependence of Alnus incana and Alnus glutinosa distribution could be attributed to these species' preference to moist floodplains. Higher altitude results in faster soil drainage, leading to suboptimal habitats and consequently lower occurrence probabilities. The relation between tree species distribution and habitat type fall in line with both MaxEnt modelling results and previous findings on pine forest being associated to poor oligotrophic soils and spruce preferences to over-moist soils (Yurkovskaya 2014).

Notably however, our results exhibited huge deviation between actual and estimated potential distribution area of aspen, with the MaxEnt model suggesting that it could be encountered so far north as the Kola Peninsula. Aspen is a mesophilic and mesotrophic species, prefers moist, rich soil and rarely could be encountered on dry sandy or swampy soils (Mikhailov 1985). In Northwestern Russia sandy soil and swampy areas that are unsuitable to well sustain growth of aspen, are common. Thus, the low occurrence rates of aspen on its northern border could be attributed to suboptimal habitats. Aspen occurrence on the Kola Peninsula could be related to habitats with rich and moist soils, for example, in the Khibiny Mountains (Mishkin 1953).

Results obtained with HMSC simulation revealed fundamental differences between temperate and boreal tree species. Not going into further details we note that historically these groups of species exhibited different behavior. Recent research show that during glacial period boreal tree species were wide spread in Central and Eastern Europe, including the Russian Plain, while temperate species were preserved in small refugia restricted to the Mediterranean and Black Sea regions (Svenning et al. 2008).

The spatial distribution of dominant tree ages was decently maps to forest use intensity over the study area. As the clearcutting in Karelia started only around 1930 (Gromtsev 2003, 2015; Volkov 2008) due to lack of infrastructure and low population density, these territories still keep very mature forest stands, which age significantly exceeds the assigned cutting age. The proportion of mostly intact natural forest landscapes in North Russia is estimated by $13 \%$ (Yaroshenko et al. 2001). On the contrary, forestry has been much more intensive in the southern regions for already several hundred years and that lead to lowered tree stand ages and substantial transition to secondary forests (Angelstam and Kuuluvainen 2004; Gromtsev 2015; Rautiainen et al. 2016). For Fennoscandia the similar consistent pattern was observed (Kuosmanen et al. 2016), although forests in Russia still remain their natural features.

Over many ages, the pyrogenic factor was governing the forest forming processes in the boreal zone (Drobyshev et al. 2015; Kuosmanen et al. 2016). Sustenance of pine stands in north and middle taiga is related to periodic stand replacing wildfires, which occur several times per millennium (Molchanov 1934; Korchagin 1954; Gromtsev 2002). While the crown fires create preferable habitats for pine and birch colonization, spruce is completely intolerant even to 
ground fires (Korchagin 1954). Thus, the fire caused death of mature trees, as well as spruce and birch offspring and the remained pine restored dominantly over the burnt area. But nowadays, the wildfire density is higher in the southern regions, where secondary deciduous and coniferous-broadleaf forests are encountered more often (Fig. 3c). Moreover, the lower density of fires in the north taiga, compared to the middle taiga, is due to shorter fire danger season and increased proportion of swampy areas (Drobyshev et al. 2014).

Nowadays, contribution of wildfire into forest shaping is gradually decreasing in the study area. For example, in Karelia the mean single burnt area decreased several times over few last decades despite of approximately constant amount of ignitions (Gromtsev 2008). Our analysis of satellite data over 2006-2016 confirms that the amount of fire events and burnt area are decreasing over the last decade. Several authors relate this phenomenon to climate change: recently the amount of heavy rainfalls $(>10 \mathrm{~mm})$ in this area has significantly increased (Filatov et al. 2012). In 1995-2010 the number of heavy rainy days was considerably higher than could be expected from long-term observations. As the heavy rainfalls often stop the fire spreading, we can hypothesize that increased precipitation amount could be the reason for decrease in significance of fire in forest forming processes.

In many parts of the study area the major changes in forest composition occurred during last several decades. In Karelia the area of pine forest was decreased by $36 \%$, the area of deciduous forests was increased more than 2.5 times, and the area of spruce forests remained unchanged (Gromtsev 2003). At the same time in the Karelian Isthmus the area of pine forests decreased by $13 \%$ in the period of 1923-1983, while the area of spruce forest increased by similar proportion (Fedorchuk et al. 2005). The optimal distribution area for pine, spruce and birch completely overlap, and with the continuing trend of reducing the frequency and intensity of fires, it is reasonably hypothesized that spruce will further replace pine and birch in these regions.

\section{Conclusions}

Local biodiversity of tree species in Northwestern Russia is determined by a set of environmental and anthropogenic factors. The north taiga is distinguished for its lowest biodiversity with no more than 3 tree species being observed at same location. On the opposite edge of the latitudinal range lie the areas with highest biodiversity, caused by high proportion of broadleaf species in community compositions. Monocultural stands could be found through the whole study area, being typically represented by pine and corresponding mainly to sandur and lake-glacial landscapes as well as sandy soils.
We have demonstrated that ICP Forests monitoring network enables to successfully establish the main qualitative and quantitative relationships of the spatial variation of tree diversity with respect to climatic, landscape, soil and anthropogenic disturbance factors. However, obtaining robust inference of the ongoing dynamics is problematic given that we have observed only a "snapshot" of the dynamic ecosystem. We believe that in order to resolve this issue, the considered data has to be of spatial time-series nature, which requires regular recensus of sites in the monitoring network.

\section{Additional file}

Additional file 1: Table S1. Number of trees in ICP Forests plots. (DOCX $15 \mathrm{~kb})$

\section{Abbreviations \\ BIO1: Annual Mean Temperature; BIO10: Mean Temperature of Warmest Quarter; BIO11: Mean Temperature of Coldest Quarter; BIO12: Annual Precipitation; BIO13: Precipitation of Wettest Month; BIO14: Precipitation of Driest Month; BIO15: Precipitation Seasonality (Coefficient of Variation); BIO16: Precipitation of Wettest Quarter; BIO17: Precipitation of Driest Quarter; BIO18: Precipitation of Warmest Quarter; BIO19: Precipitation of Coldest Quarter; BIO2: Mean Diurnal Range (Mean of monthly (max temp - min temp)); $\mathrm{BIO}$ : Isothermality (BIO2/BIO7) (* 100); BIO4: Temperature Seasonality (standard deviation *100); BIO5: Max Temperature of Warmest Month; BIO6: Min Temperature of Coldest Month; BIO7: Temperature Annual Range (BIO5-BIO6); BIO8: Mean Temperature of Wettest Quarter; BIO9: Mean Temperature of Driest Quarter; GPS: Global Positioning System; ICP Forest: International Co-operative Programme on Assessment and Monitoring of Air Pollution Effects on Forests}

\section{Acknowledgements}

We thank the Centre for Forest Health of the Leningrad region for assistance in conducting the field work.

Availability of data and materials

All data is available upon request to the Ministry of Natural Resources and Ecology of the Russian Federation.

\section{Authors' contributions}

ET and NL conceived the ideas; ET, AP, SK and MS designed the methodology; NS and GT devised and performed statistical analyses; ET, NS, GT and NL wrote the manuscript; GT prepared manuscript for submission. All authors contributed significantly to the drafts and gave their final approvals.

\section{Funding \\ We acknowledge the primary funding from the Russian Science Foundation (Grant no. 16-17-10284), Presidium of the Russian Academy of Science (Project no. 0110-2015-0005: Forest tree species in Russia: their distribution, wood stock, contribution to ecosystem functions and services), Russian Foundation for Basic Research (Grant no. 17-05-00300 to AP) and LUOVA graduate school at University of Helsinki (PhD grant for GT).}

Authors' information

NL is the Head of laboratory; ET, NS, SK, AP, MS are senior researchers; GT is a PhD student.

Ethics approval and consent to participate Not applicable.

Consent for publication Not applicable. 


\section{Competing interests}

The authors declare that they have no competing interests.

\section{Author details}

${ }^{1}$ Center of Forest Ecology and Productivity RAS, 117997, Profsoyusnaya 84/ 32, Moscow, Russia. ${ }^{2}$ Department of Biosciences Metapopulation Research Centre, University of Helsinki, Helsinki, Finland. ${ }^{3}$ Institute of Physicochemical and Biological Problems in Soil Science RAS, Puschino, Russia.

\section{Received: 11 August 2017 Accepted: 20 November 2017}

Published online: 15 December 2017

\section{References}

Angelstam P, Kuuluvainen T (2004) Boreal forest disturbance regimes, successional dynamics and landscape structures - a European perspective. Ecol Bull 51:117-136

Assmann E (1970) The principles of forest yield study: studies in the organic production, structure, increment, and yield of forest stands. Pergamon Press, Oxford, New York

Brus DJ, Hengeveld GM, Walvoort DJJ, Goedhart PW, Heidema AH, Nabuurs GJ, Gunia K (2012) Statistical mapping of tree species over Europe. Eur J. Forest Res 131(1):145-157

Caley MJ, Schluter D (1997) The relationship between local and regional diversity. Ecology 78:70-80

Core Development Team R (2016) R: a language and environment for statistical computing. R Foundation for Statistical Computing, Vienna, Austria

Crowther TW, Glick HB, Covey KR, Bettigole C, Maynard DS, Thomas SM, Smith JR, Hintler G, Duguid MC, Amatulli G, Tuanmu MN, Jetz W, Salas C, Stam C, Piotto D, Tavani R, Green S, Bruce G, Williams SJ, Wiser SK, Huber MO, Hengeveld GM, Nabuurs GJ, Tikhonova E, Borchardt P, Li CF, Powrie LW, Fischer M, Hemp A, Homeier J, Cho P, Vibrans AC, Umunay PM, Piao SL, Rowe CW, Ashton MS, Crane PR, Bradford MA (2015) Mapping tree density at a global scale. Nature 525:201-205

Drobyshev I, Bergeron Y, Linderholm HW, Granström A, Niklasson M (2015) A 700year record of large fire years in northern Scandinavia shows large variability and increased frequency during the 1800s. J Quat Sci 30(3):211-221

Drobyshev I, Granström A, Linderholm HW, Hellberg E, Bergeron Y, Niklasson M (2014) Multi-century reconstruction of fire activity in northern European boreal forest suggests differences in regional fire regimes and their sensitivity to climate. J Ecol 102:738-748

Ecological Atlas of Russia (2002) ZAO Karta. St-Petersburg, Moscow

Eitingen GR (1959) Forestry. Selhozgiz, Moscow

Evseev OV (ed) (2002) The Ecological Atlas of Russia. ZAO Karta, St-Petersburg, Moscow. FAO (2015) Global Forest Resources Assessment. Russian Federation

Fedorchuk VN, Neshatayev VY, Kuznetsova ML (2005) Forest ecosystems of the north-western regions of Russia: typology, dynamics, forests management features. Saint-Petersburg Forestry Research Institute, St. Petersburg

Ferretti M (2013) A quality assurance framework for designing forest monitoring programs. In: Ferretti M, Fischer R (eds) Developments in environmental science. Elsevier, Amsterdam. pp 77-90

Filatov NN, Nazarova LE, Georgiev AP, Semenov AV, Antsiferova AR, Ozigina VN, Bogdan MI (2012) Climate changes and variability in the north of European Russia and their impact on water bodies. Arctic: Ecology and Economy 2:80-93

Gamfeldt L, Snäll T, Bagchi R, Jonsson M, Gustafsson L, Kjellander P, Ruiz-Jaen MC, Fröberg M, Stendah J, Philipson CD, Mikusiński G, Andersson E, Westerlund B, Andrén H, Moberg F, Moen J, Bengtsson J (2013) Higher levels of multiple ecosystem services are found in forests with more tree species. Nat Commun 4. doi:10.1038/ncomms 2328

Gromtsev A (2002) Natural disturbance dynamics in the boreal forests of European Russia: a review. Silv Fenn 36(1):41-55

Gromtsev AN (2003) A retrospective analysis of general trends in the anthropogenic dynamics of forest cover in the north-west of the taiga zone of Russia. Proceedings of the Karelian research Center of the Russian Academy of sciences. Biogeography of Karelia (flora and fauna of taiga). Ecosystems 4:6-18

Gromtsev AN (2008) Fundamentals of landscape ecology of European taiga forests in Russia. Karelian Research Center of the RAS, Petrozavodsk

Gromtsev AN (2015) Forests and their multi-purpose use in the north-west of the European part of the taiga zone of Russia. Karelian Research Center of the RAS, Petrozavodsk

Hijmans RJ, Cameron SE, Parra JL, Jones PG, Jarvis A (2005) Very high resolution interpolated climate surfaces for global land areas. Intl. J Clim 25:1965-1978
Hunter W (2012) Recent advances and issues in environmental science. Apple Academic Press, Oakville, Ont

Huntley B (1993) Species-richness in north-temperate zone forests. J Biogeogr 20(2):163-180

Huston MA (1994) Biological diversity: the coexistence of species on changing landscapes. Cambridge University Press, Cambridge

Jones CG, Lawton JH, Shachak M (1997) Positive and negative effects of organisms as physical ecosystem engineers. Ecology 78:1946-1957

Jones CG, Lawton JH, Shackak M (1994) Organisms as ecosystem engineers. Oikos 69:373-386

Korchagin AA (1954) Influence of fires on the forest vegetation and its recovering after fire in the European north. Proceedings of BIN RAS, pp 75-148

Körner C, Basler D, Hoch G, Kollas C, Lenz A, Randin CF, Vitasse Y, Zimmermann NE (2016) Where, why and how? Explaining the low-temperature range limits of temperate tree species. J Ecol 104:1076-1088

Kuosmanen N, Seppä H, Alenius T, Bradshaw RHW, Clear Jl, Filimonova L, Heikkilä M, Renssen H, Tallavaara ML, Reitalu T (2016) Importance of climate, forest fires and human population size in the Holocene boreal forest composition change in northern Europe. Boreas 45:688-702

Latham RE, Ricklefs RE (1993) Global patterns of tree species richness in moist forests: energy-diversity theory does not account for variation in species richness. Oikos 67:325-333

Lukina NV, Orlova MA, Gornov AV, Kryshen AM, Kuznetsov PV, Knyazeva SV, Smirnov VE, Bakhmet ON, Eydlina SP, Ershov W, Zukert NV, Isaeva LG (2013) Assessment of sustainable forest management criteria using indicators of the international programme ICP forests. Contemp Probl Ecol 6:734-745

Lupian EA, Bartalev SA, Tolpin VA, Zarko VO, Krasheninnikova YS, Oksyukevich AY (2014) Usage of satellite service VEGA in regional systems of remote monitoring Modern problems of the Earth remote satellite sensing 11:215-232

Meier ES, Lischke H, Schmatz DR, Zimmermann NE (2012) Climate, competition and connectivity affect future migration and ranges of European trees. Glob Ecol Biogeogr 21:164-178

Mikhailov LE (1985) Aspen. Agropromizdat, Moscow

Mishkin BA (1953) Flora of Khibin's mountains: analyses and history. Izdatelstvo AS USSR, Moscow-Leningrad

Molchanov AA (1934) Forest fire damage and loss of stands. Forest Industry, Moscow

Morozova OV (2009) Spatial trends in the taxonomic richness of the Eastern European flora. In: Golovatch SI, Makarova OL, Babenko AB, Penev LD (eds) Species and Communities in Extreme Environments. Pensoft Publishers \& KMK Scientific Press, Sofia-Moscow. pp 279-300.

Ovaskainen O, Roy DB, Fox R, Anderson BJ (2016) Uncovering hidden spatial structure in species communities with spatially explicit joint species distribution models. Method Ecol Evol 7:428-436

Ovaskainen O, Tikhonov G, Norberg A, Blanchet FG, Duan L, Dunson D, Roslin T, Abrego N (2017) How to make more out of community data? A conceptual framework and its implementation as models and software. Ecol Lett 20:561-576

Phillips BF, Booth JD, Cobb JS, Jeffs AG, McWilliam P (2006) Larval and postlarval ecology. Lobsters: biology, management, aquaculture and. Fisheries:231-262

Phillips SJ, Dudík M (2008) Modeling of species distributions with Maxent: new extensions and a comprehensive evaluation. Ecography 31:161-175

Pearson RG, Dawson TP (2003) Predicting the impacts of climate change on the distribution of species: are bioclimate envelope models useful? Global Ecology \& Biogeography 12:361-371

Pollock L, Tingley R, Morris WK, Golding N, O'Hara RB, Parris KM, Vesk PA, Mccarthy MA (2014) Understanding co-occurrence by modelling species simultaneously with a joint species distribution model (JSDM). Method. Ecol Evol 5:397-406

Rautiainen A, Virtanen T, Kauppi PE (2016) Land cover change on the isthmus of Karelia 1939-2005: agricultural abandonment and natural succession. Environm Sci Policy 55(1):127-134

Svenning JC, Fitzpatrick MC, Normand S, Graham CH, Pearman PB, Iverson LR, Skov F (2010) Geography, topography, and history affect realized-to-potential tree species richness patterns in Europe. Ecography 33:1070-1080

Svenning JC, Normand S, Kageyama M (2008) Glacial refugia of temperate trees in Europe: insights from species distribution modelling. J Ecol 96:1117-1127

Svenning JC, Skov F (2005) The relative roles of environment and history as controls of tree species composition and richness in Europe. J Biogeogr 32:1019-1033

Sykes MT, Prentice IC, Cramer W (1996) A bioclimatic model for the potential distributions of north European tree species under present and future climates. J Biogeogr 23(2):203-233 
Tröltzsch K, Brusselen JV, Schuck A (2009) Spatial occurrence of major tree species groups in Europe derived from multiple data sources. Forest ecology. Manage 257(1):294-302

Vetluzhskikh NV (2016) Occurrence of tree species in forest phytocenoses of West Siberia along a latitudinal gradient. Tomsk State University. J Biol 1(33):6-17

Volkov AD (2008) Karelian forest types. Karelian scientific center RAS, Petrozavodsk Warton DI, Blanchet FG, O'Hara RB, Ovaskainen O, Taskinen S, Walker SC, Hui FKC (2015) So many variables: joint modeling in community ecology. Trend Ecol Evol 30:766-779

Wirth C (2005) Fire regime and tree diversity in boreal forests: implications for the carbon cycle. In: Scherer-Lorenzen M, Körner C, Schulze ED (eds) Forest diversity and function, Ecological studies (analysis and synthesis), vol 176. Springer, Berlin, Heidelberg, pp 309-344

Woodward Fl, Williams BG (1987) Climate and plant distribution at global and local scales. Vegetatio 69(1-3):189-197

Yaroshenko AY, Potapov PV, Turubanova SA (2001) The last intact Forest landscapes of northern European Russia. Greenpeace Russia, Moscow

Yurkovskaya TK (2014) Latitudinal boundaries of vegetation cover and ecotones along the Green Belt of Fennoscandia. Proceedings of the Karelian Scientific Center RAS 6:53-63

\section{Submit your manuscript to a SpringerOpen ${ }^{\circ}$ journal and benefit from:}

- Convenient online submission

- Rigorous peer review

- Open access: articles freely available online

- High visibility within the field

- Retaining the copyright to your article

Submit your next manuscript at $\boldsymbol{s p r i n g e r o p e n . c o m ~}$ 